University of Nebraska - Lincoln

DigitalCommons@University of Nebraska - Lincoln

\title{
Parental Divorce, Marital Conflict and Children's Behavior Problems: A Comparison of Adopted and Biological Children
}

Paul R. Amato

Pennsylvania State University

Jacob Cheadle

University of Nebraska-Lincoln, jcheadle2@unl.edu

Follow this and additional works at: https://digitalcommons.unl.edu/sociologyfacpub

Part of the Sociology Commons

Amato, Paul R. and Cheadle, Jacob, "Parental Divorce, Marital Conflict and Children's Behavior Problems: A Comparison of Adopted and Biological Children" (2008). Sociology Department, Faculty Publications. 91.

https://digitalcommons.unl.edu/sociologyfacpub/91

This Article is brought to you for free and open access by the Sociology, Department of at DigitalCommons@University of Nebraska - Lincoln. It has been accepted for inclusion in Sociology Department, Faculty Publications by an authorized administrator of DigitalCommons@University of Nebraska - Lincoln. 


\section{Parental Divorce, Marital Conflict and Children's Behavior Problems: A Comparison of Adopted and Biological Children}

Paul R. Amato, Pennsylvania State University

Jacob E. Cheadle, University of Nebraska-Lincoln

We used adopted and biological children from Waves 1 and 2 of the National Survey of Families and Households to study the links between parents' marital conflict, divorce and children's behavior problems. The standard family environment model assumes that marital conflict and divorce increase the risk of children's behavior problems. The passive genetic model assumes that parents' and children's behavior are linked because of genetic transmission from parents to children. The child effects model assumes that parents' marital distress is the result of (rather than the cause of) children's behavior. Our analysis shows that the associations between parents' divorce and marital conflict and children's behavior problems are comparable for biological and adopted children. Moreover, the primary direction of influence appears to run from parents to children. Taken together, these results provide support for the standard family environment model.

A large number of studies conducted during the past three decades have shown that children with divorced parents have an elevated risk of a variety of problems, including conduct disorders, emotional disturbances, difficulties with social relationships and academic failure (Amato 2000). This topic has been of interest to social scientists from a variety of disciplines, including demography (Cherlin 1999), family sociology (Booth and Amato 2001), education (Pong, Dronkers and Hampden-Thompson 2003), criminology (Thornberry, Smith, Rivera, Huizinga and StouthamerLoeber 1999), economics (Havemann 1994), and child psychology (Emery 1999). Similarly, studies have shown that in the absence of divorce, exposure to chronic, unresolved conflict between parents increases the risk of comparable problems for children (Amato and Booth 1997; Emery 1999; Krishnakumar and Buehler 2000). Not all children who experience divorce or who grow up with chronically discordant parents develop serious problems. Nevertheless, these findings indicate that further research on the causal linkages between these variables is warranted.

Direct correspondence to Paul R. Amato, Department of Sociology, Pennsylvania State University, 211 Oswald Tower, University Park, PA 16802. Telephone: (814) 867-7393. E-mail:pxa6@psu.edu. 


\section{0 • Social Forces Volume 86, Number 3 • March 2008}

Three broad theoretical perspectives are relevant to this literature. The first perspective, which we refer to as the standard family environment model, is the most popular. This perspective assumes that dysfunctional two-parent families and many single-parent families formed through divorce are less than optimal settings for children's socialization and development. Consequently, exposure to these environments increases the risk of a variety of problems for the children.

In recent years, researchers in the field of behavior genetics have challenged the standard family environment model. Studies from this literature suggest that many of the links between family risk factors and children's adjustment - links that were once thought to be entirely environmental - have a strong genetic component (Harris 1998; Towers, Spotts and Neiderhiser 2001; Rowe 1994). According to this perspective, parents with problematic personality traits, such as neuroticism or a predisposition to engage in antisocial behavior, are more likely than other parents to experience marital discord and end their marriages in divorce. Because parents transmit these traits to their progeny genetically, children in these families are prone to a variety of disorders. According to this scenario, the links between parents' marital distress and children's behavioral and emotional problems are spurious. Genetically inherited predispositions are the causal mechanism connecting parents' and children's problems.

A child effects model also challenges the standard family environment model. Advocates of this perspective point out that the vast majority of studies in this literature involve correlations derived from cross-sectional data. An alternative explanation for these results is equally plausible: Children's behavior and emotional problems are a cause of discord between parents. Cross-sectional studies cannot distinguish between these two explanations. (For a review of these perspectives, see Ambert 2001; Crouter and Booth 2003.)

This article compares the standard family environment model, the genetic model and the child effects model. We compare adopted and biological children to estimate the role of genetic factors in explaining the association between parental divorce and children's behavior problems, and we use longitudinal data to estimate the direction of causal influence between parents' marital conflict and children's behavior problems. Data come from Waves 1 and 2 of the National Survey of Families and Households.

\section{Theory}

\section{The Standard Family Environment Model}

The standard model used by most social scientists assumes that the quality and stability of the parents' marriage affects children's chances 
Figure 1. Links Between Parents' Marital Conflict and Divorce and Children's Behavior Problems

Standard Family Effects Model

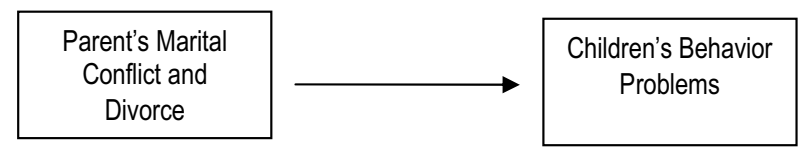

Passive Genetic Effects Model

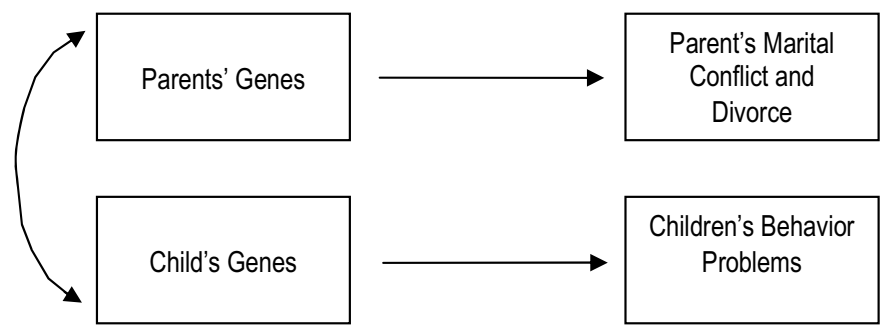

Child Effects Model

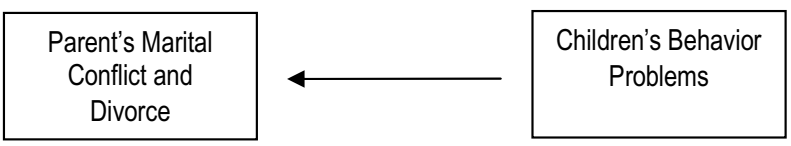

of developing a variety of emotional, behavioral and academic problems. This model, which involves a direct path from parents' marital discord and divorce to children's behavior problems, is illustrated in Figure 1.

Why should exposure to marital conflict and instability have negative consequences for children? Several mechanisms are likely to be responsible. First, observing overt conflict between parents is a direct stressor for children. Observational studies reveal that children react to interparental conflict with fear, anger or the inhibition of normal behavior (Cummings 1987). Preschool children - who tend to be egocentric may blame themselves for marital conflict, resulting in feelings of guilt and lowered self-esteem (Grych and Fincham 1990). Conflict between parents also tends to spill over and negatively affect the quality of parents' interactions with their children (Davies and Cummings 1994; Hetherington and Clingempeel 1992). For example, Gerard, Krishnakumar and Buehler (2006) found that the associations between marital conflict and children's externalizing and internalizing problems were largely mediated by parents' use of harsh punishment and parent-child conflict. Furthermore, through 
modeling verbal or physical aggression, parents "teach" their children that disagreements are resolved through conflict rather than calm discussion. As a result, children may not learn the social skills (such as the ability to negotiate and reach compromises) that are necessary to form mutually rewarding relationships with peers (Amato and Booth 2001).

Divorce is not a single event but a process that unfolds over time. Family problems, such as substance abuse and economic hardship, are predictors of divorce (Amato and Previti 2003). Divorce is often preceded by a period of overt conflict or mutual disengagement between spouses. In addition, divorce is often followed by a series of difficult circumstances for children, including reduced contact with the noncustodial parent, continuing rancor between parents, a decline in children's standard of living, and a move often to neighborhoods with fewer community resources (Amato 2000). In addition, most parents find new partners following divorce, and many children find dealing with stepparents (whether married or cohabiting) challenging (Hetherington and Jodl 1994). The creation of new parental unions also means that many children experience additional union dissolutions, which adds to the turmoil in their lives (Fomby and Cherlin 2007). Overall, divorce is a summary variable that represents a variety of circumstances that many children experience as stressful.

\section{The Passive Genetic Model}

Behavioral genetics research indicates that many personality traits, such as a depression, neuroticism and antisocial behavior, have a strong genetic component (Plomin 1994). These studies typically compare concordance for behaviors across monozygotic (identical) and dizygotic (fraternal) twin pairs. For a particular trait, if the correlation between monozygotic twins is larger than the correlation between dizygotic twins, then genetic factors are implicated. Twin studies generally indicate that half or more of the variance in many behavioral predispositions and personality traits (across a variety of domains) is due to genetic factors. Studies that incorporate a broader range of sibling pairs (monozygotic twins, dizygotic twins, nontwin full siblings, half-siblings and step-siblings) yield similar results (Reiss, Neiderhiser, Hetherington and Plomin 2000.)

Research indicates that spouses who exhibit antisocial personality traits, show symptoms of neuroticism or experience chronic depression are more likely to report marital problems and end their marriages through divorce than are other spouses (Brody, Neuman and Forehand 1988; Capaldi and Patterson 1991). Consistent with these findings, behavioral genetics studies show that adults' reports of general family conflict, marital satisfaction and divorce all have significant genetic components (Jockin, McGue and Lykken 1996; McGue and Lykken 1992; Plomin, McClearn, Pedersen, 
Nesselroade and Bergeman 1989; Towers, Spotts and Neiderhiser 2001). Of course, it is unlikely that a "divorce" or "marital unhappiness" gene exists. Nevertheless, genetically inherited traits may predispose people to act in ways that lower the quality of long-term relationships and increase the risk of marital dissolution.

The passive genetic model is represented in Figure 1 as a direct path between parents' genetic predispositions and marital distress. Children share approximately 50 percent of their genes with each parent, which is represented in Figure 1 as a correlation between parents' and children's genes. These shared genetic predispositions mean that parents' marital distress and children's behavior problems are positively correlated. This observed correlation, however, is either partly or completely spurious. Because parents' provide genes as well as environments to their children, observed correlations between parents' and children's behavior substantially overestimate the effect of the family environment.

\section{The Child Effects Model}

This model assumes that the links between children's and parents' behavior are due to the causal effect of children on parents. Bell (1968) first drew attention to this possibility when he pointed out that most correlational studies cannot distinguish between the parent's influence on the child and the child's influence on the parent. Since then, the belief that children affect the behavior of their parents has gained wide acceptance among social scientists (Ambert 2001; Booth and Crouter 2003). For example, a substantial number of studies show that mothers of "difficult" infants infants who express a good deal of negative emotionality - report less confidence and more symptoms of stress and depression than do mothers of other infants (Crockenberg and Leerkes 2003).

If parents do not affect their children as much as one tends to think, then what is the source of variability in children's behavior? Genes represent a plausible source. An evocative genetic model assumes that children's temperaments, based on genetic predispositions, evoke certain behaviors on the part of parents (Reiss et al. 2000). For example, badly behaved children may increase the level of tension between parents, leading to a positive correlation between marital conflict and children's misbehavior. Studies showing that parents treat biological siblings more similarly than they treat adopted siblings are consistent with an evocative genetic model. In other words, genetically based traits that biological (but not adopted) siblings share should evoke similar responses from parents (Reiss 2003).

The child effects model does not necessarily require the assumption that all child problems are genetically inherited. Children and adolescents may exhibit behavior problems due to a variety of nonparental sources, 
such as peers, neighborhoods or the media. Irrespective of the source of these problems, advocates of this perspective assume that parents' behavior (including marital conflict) is often a reaction to, rather than a cause of, child misbehavior.

\section{Empirical Support for the Three Models}

Some researchers have used sophisticated statistical methods to assess whether parental separation has a causal effect on children, including fixed-effects models (Cherlin, Chase-Lansdale and McRae 1998), biprobit analyses with correlated error terms (McLanahan and Sandefur 1994), instrumental variable approaches (Gruber 2004), and propensity score analysis (Amato 2004). These studies generally claim to find evidence for a causal effect of family disruption on children's well-being, net of observed and unobserved selection factors. Nevertheless, these studies contain important limitations. For example, many of these methods, such as fixedeffects models, control for omitted variables that do not vary over time. Genetic factors, however, are not constant. Instead, particular genes are active or inactive at different stages of development, and environmental events can "turn off" or "activate" certain genes (Reiss et al. 2000). For these reasons, existing studies provide suggestive but not conclusive evidence against genetic explanations.

Other studies have used genetically informed designs to assess this issue. Although twin designs are commonly used in this literature, another rigorous design involves comparisons of adopted and biological children. McCartney (2003) argued that adoption studies are more powerful than twin studies for assessing genetic and environmental influences on children. Adoption studies offer a quasi-experimental approach, with the correlations between parents' and children's behavior reflecting pure environmental effects, uncontaminated by genetic factors. Researchers who use this design examine the links between divorce (or some other family variable) on outcomes among biological and adopted children. If the association between parental divorce and a child outcome is similar for biological and adopted children, then the standard family environment model is supported. This conclusion is warranted because adoptive children and their social parents are not related biologically. If an association between parental divorce and a child outcome appears among biological children but not among adopted children, however, then the passive genetic model is supported. Finally, if an association appears among both groups of children, but if the association is stronger for biological than for adopted children, then both perspectives are supported.

Although several studies have used this strategy for studying parental divorce, the results are mixed. Brodzinsky, Hitt and Smith (1993) found 
that the associations between parental divorce and several forms of child adjustment (internalizing behavior, externalizing behavior and social competence) were similar for adopted and biological children - a pattern consistent with the standard family environment model. Similarly, O'Connor, Caspi, DeFries and Plomin (2000) used data from the Colorado Adoption Project to examine the links between parental divorce and several child outcomes. In this study, children who experienced parental divorce tended to exhibit more behavior problems, were more likely to engage in substance abuse, had lower levels of academic achievement, and scored lower on measures of social adjustment than did other children. The associations between parental divorce and measures of children's behavior problems and substance use were comparable for adopted and biological children - a finding that supports the standard family environment model. In contrast, the associations between parental divorce and measures of children's school achievement and social adjustment were apparent among biological children but not among adopted children - findings that support the passive genetic model.

Few studies have assessed whether the links between parents' marital distress and children's behavior problems are due to child effects. Nevertheless, some related research supports this possibility. Hetherington and Kelly (2002) used cross-lagged models to show that stepfather involvement was driven primarily by stepchildren's behavior, rather than the reverse. Similarly, studies have shown that parental monitoring is largely a function of children's willingness to disclose information to parents, rather than parents' active efforts to supervise their children (Crouter and Head 2002). For example, Stattin and Kerr (2000) found that children's willingness to engage in self-disclosure was a stronger predictor of parents' knowledge about their children's lives than were parents' use of questioning or their emphasis on following rules. Although not directly related to marital conflict, these studies suggest that many findings that earlier researchers attributed to parental influence actually reflect children's influence on parents.

\section{Contributions of the Present Study}

The present study makes three contributions to the research literature. First, the number of studies that have compared adopted and biological children is small. Moreover, prior studies have not been based on national, random samples. Brodzenski et al. (1993) relied on a small convenience sample of 59 children from divorced families and 64 children from nondivorced families. The O'Connor et al. (2000) study was based on children selected from two adoption agencies and several hospitals in Colorado. Although this sample size was relatively large for a psychological study (188 adopted and 210 biological children), the results of their research, although 
informative, cannot be generalized to a larger population. Given the small number of relevant studies, additional studies that compare adopted and biological children are necessary to draw firmer conclusions about the role of genetic vs. family environment factors in shaping children's behavior problems. The present study contributes to this goal by estimating the effects of marital conflict and divorce among adopted and biological children from Waves 1 and 2 of the National Survey of Families. Although this data set is based on a national sample of children and families, it is limited by the fact that any random sample (without oversampling) will produce only a small number of adopted children. Second, the current study focuses not only on parental divorce, but also on parents' marital conflict in continuously intact marriages. And third, two-wave longitudinal data make it possible to assess the direction of influence between marital conflict and children's behavior problems.

\section{Methods}

\section{Sample}

The first wave of the NSFH was conducted in 1987-88 and involved a multistage probability sample of 13,007 adult respondents (Sweet, Bumpass, and Call 1988). In the main interview, parents answered an extensive series of questions about a focal child. Parents also answered a shorter series of questions about all children in the household between the ages of 5 and 18, and these latter data were used in the present study. The first analysis involved two groups: (1. children who lived continuously with two biological or adoptive parents, and (2. children who experienced the divorce of their biological or adoptive parents and whose custodial parent had not remarried. Children born outside of marriage or who experienced the death of a biological or adoptive parent were omitted. Children adopted by a stepparent also were omitted, because these children are genetically related to the custodial parent. These restrictions resulted in a sample of 4,997 children living in 2,839 households. Of these children, 4,877 were biological and 120 were adopted.

The second analysis was based on longitudinal data. Interviewers contacted respondents again in 1992-94. (See Sweet and Bumpass, 1996, for details.) Of the 2,839 parent respondents in the first wave, 17 percent did not complete the second interview. ${ }^{1}$ In addition, many children aged out of the sample, that is, they were older than 18 in Wave 2. Although it was easy to match the focal child across interviews, it was difficult to match other children in the household because their identification numbers differed. Consequently, the two-wave analysis was restricted to the focal child - the one child who could be matched 
unambiguously across surveys. This decision resulted in a sample of 1,394 biological and 50 adopted children.

\section{Variables}

In both waves, the main respondent was asked a series of binary questions about behavior problems among all of the children living in the household between the ages of 5 and 18: (1. Have any of these children ever repeated a grade? (2. In the past year, have you been asked to meet with a teacher or principal because of behavioral problems of any of the children? (3. Have any of the children ever been suspended or expelled from school? (4. Have any of the children ever been in trouble with the police? (5. Have any of the children ever seen a doctor or therapist about any emotional or behavioral problems? (6. Sometimes, for one reason or another, some children are particularly difficult to raise. Would you describe any of your children as particularly difficult to raise? (An item on running away from home was omitted because few parents reported this problem.) Data from each child in the household appeared in the analysis.

Parental divorce at Wave 1 was a dichotomous variable that indicated whether children's biological or adopted parents had divorced prior to the first interview ( $0=$ continuously married, $1=$ divorced $)$.

Among married parents, marital conflict was based on the following six questions: "How often, if at all, in the last year have you had open disagreements about each of the following: Household tasks? Money? Spending time together? Sex? In-laws? The children?" Response options were $1=$ never, 2 = less than once a month, 3 = several times a month, 4 = about once a week, 5 = several times a week, 6 = almost every day. (We omitted an additional question on having another child because it was weakly correlated with the other items.) Both the main respondent and the respondent's spouse answered these questions in Waves 1 and 2. Alpha reliability coefficients were .77 for respondents in Wave 1, .80 for spouses in Wave 1, .78 for respondents in Wave 2, and .76 for spouses in Wave 2. Correlations between respondents' and spouses' scores were $r=.41$ in Wave 1 and $r=.35$ in Wave 2 (both $p<.001$ ).

Control variables included the child's gender $(0=$ son, $1=$ daughter $)$, the child's age in years, the number of siblings living in the household, the main respondent's gender ( $0=$ father, $1=$ mother $)$, the main respondent's race (with separate dummy variables for black and Latino), and the main respondent's education ( 0 = no formal education, $20=$ doctorate). Income did not serve as a control variable in the divorce analysis, because a decline in children's standard of living is a common result of divorce (McLanahan and Sandefur 1994). Income was controlled, however, in the marital conflict analysis. ${ }^{2}$ 


\section{Analytic Strategy}

To analyze the six behavior problems noted earlier, Mp/us software created a latent variable based on binary indicators (Muthén and Muthén 2005). This approach is equivalent to an item response theory model. IRT treats discrete outcomes as reflections of an underlying latent trait that is assumed to be normally distributed in the population (Hambleton, Swaminathan and Rogers 1991). IRT has been used successfully in the criminology literature to deal with the shortcomings of traditional scales based on counts of delinquent or deviant activities, which tend to be highly skewed (Osgood, McMorris and Potenza 2002). The factor loadings were based on robust weighted least squares estimation of probit regression coefficients, rather than the more commonly used maximum likelihood estimation of logistic regression coefficients. Because numerical integration is not required with weighted least squares, estimation is much faster. Moreover, maximum likelihood estimation was not available in Mplus for some of the models. ${ }^{3}$

In the cross-sectional analysis, Wave 1 data were used to estimate the effect of parental divorce on children's behavior problems. The longitudinal analysis focused on the associations between parents' marital conflict and children's behavior problems in Wave 2. Mplus estimated simultaneous reciprocal paths between (a) parents' marital conflict at $t_{2}$ and children's behavior problems at $t_{2}$ and (b) children's behavior problems at $t_{2}$ and parents' marital conflict at $t_{2}$. The corresponding Wave 1 variables served as instruments to identify the model. Reciprocal effects models are useful because they reflect the assumption that the family is a dynamic system in which changes in one component are accompanied by changes in other components. (See Bollen 1989 for a discussion of recursive models, and Amato and Booth 1995 for an empirical example. $)^{4}$

Mplus software adjusted the standard errors for the clustering of cases (children) within families and sample weights for the descriptive data in Table 1. We did not weight the data in the regression analyses because some of the independent variables were used in the construction of the NSFH weight variable (Winship and Radbill 1994).

\section{Results}

\section{Parental Divorce and Children's Behavior Problems}

Table 1 shows the means and standard deviations for Wave 1 sample characteristics (in the first three columns) with separate values for biological and adopted children. Biological and adopted children did not differ with respect to age, gender, number of siblings or whether 
Table 1: Descriptive Statistics by Child's Adoption Status

\begin{tabular}{lcccc}
\hline Variable & & $\begin{array}{c}\text { Biological } \\
\text { Children }\end{array}$ & $\begin{array}{c}\text { Adopted } \\
\text { Children }\end{array}$ & $\boldsymbol{t} / \mathbf{\chi}^{2}$ \\
\hline Child Age & $\mathrm{M}$ & 11.82 & 12.32 & 1.50 \\
& $(\mathrm{~S})$ & $(3.81)$ & $(3.75)$ & \\
Daughter & $\%$ & 51 & 49 & .24 \\
Number of Siblings & $\mathrm{M}$ & 1.75 & 1.51 & 1.76 \\
& $(\mathrm{~S})$ & $(1.43)$ & $(1.27)$ & \\
Mother Respondent & $\%$ & 56 & 60 & 1.07 \\
Parent Education & $\mathrm{M}$ & 12.80 & 14.42 & $5.77^{* * *}$ \\
& $(\mathrm{~S})$ & $(3.18)$ & $(3.31)$ & \\
Household Income & $\mathrm{M}$ & 43.69 & 62.77 & $4.23^{* * *}$ \\
& $(\mathrm{~S})$ & $(51.39)$ & $(54.61)$ & \\
Black & $\%$ & 11 & 4 & $5.43^{*}$ \\
Hispanic & $\%$ & 12 & 3 & $9.56^{* *}$ \\
Parents Divorced & $\%$ & 12 & 9 & .83 \\
Behavior Problems & $\mathrm{M}$ & -.10 & .44 & $6.69^{* * *}$ \\
& $\mathrm{~S})$ & $(.92)$ & $(1.26)$ & \\
\hline
\end{tabular}

Note: Means and standard deviations in table are weighted. Maximum sample size is 4,877 biological children and 120 adopted children (unweighted). For significance testing, standard errors are adjusted for clustering of children within families.

${ }^{*} \mathrm{p}<.05 \quad{ }^{* *} \mathrm{p}<.01 \quad{ }^{* * *} \mathrm{p}<.001$. (two-tailed).

the mother (or father) served as the primary respondent. Compared with biological children, adopted children had better educated parents, more family income and were less likely to be African American or Hispanic. Consistent with prior research, these results indicate that adopted children tend to live in relatively advantaged households (Ceballo, Lansford, Abbey and Stewart 2004; Hamilton, Cheng and Powell 2007). Despite these structural advantages, adopted children scored about one-half of a standard deviation higher than did biological children on the behavior problems measure. This result is consistent with prior work showing that adopted children are at greater risk than are biological children for a variety of behavioral and emotional problems (Lansford, Ceballo, Abbey and Stewart 2001).

Although not shown in Table 1, we also looked specifically at the sample of children who experienced divorce. Adopted and biological children with divorced parents did not differ with respect to gender or age. Mean age at the time of divorce, however, was eight years for adopted children and six years for biological children $(p<.05)$. Correspondingly, the mean number of years since divorce was five for adopted children and seven for biological children $(p<.05)$. These differences were not problematic, however, because supplementary analyses showed that neither age at divorce nor the length of time since divorce was correlated significantly with children's behavior problems. 
1150 • Social Forces Volume 86, Number 3 • March 2008

Table 2: Regression of Children's Behavior Problems on Parental Divorce

\begin{tabular}{lcccccc}
\hline \multirow{2}{*}{ Variables } & \multicolumn{3}{c}{ Biological Children } & \multicolumn{3}{c}{ Adopted Children } \\
& $\mathbf{b}$ & (SE) & beta & b & (SE) & beta \\
\hline Divorce & $.434^{* * *}$ & $(.031)$ & .202 & $.812^{\star * *}$ & $(.278)$ & .252 \\
Parent Education & $-.013^{*}$ & $(.005)$ & -.041 & .019 & $(.032)$ & -.052 \\
Parent Black & $-.104^{* *}$ & $(.036)$ & -.040 & -.371 & $(.396)$ & -.084 \\
Parent Hispanic & $-.140^{* *}$ & $(.045)$ & -.049 & -.584 & $(.492)$ & -.104 \\
Number of Siblings & -.025 & $(.010)$ & -.036 & .116 & $(.084)$ & .120 \\
Child Age & $.047^{* * *}$ & $(.004)$ & .179 & $.064^{*}$ & $(.029)$ & .189 \\
Daughter & $-.294^{* * *}$ & $(.027)$ & -.148 & -.403 & $(.215)$ & -.164 \\
Mother Respondent & $.067^{*}$ & $(.031)$ & .032 & -.228 & $(.225)$ & -.089 \\
$\mathrm{R}^{2}$ & .113 & & & .167 & & \\
\hline
\end{tabular}

Note: $\mathrm{N}=4,877$ biological children and 120 adopted children. Estimates are based on Mplus with behavior problems represented as a binary latent variable. Because the dependent variable is standardized, $b$ coefficients can be interpreted as effect sizes. Standard errors are adjusted for clustering of children within families.

${ }^{*} \mathrm{p}<.05 \quad{ }^{* *} \mathrm{p}<.01 \quad{ }^{* * *} \mathrm{p}<.001$. (two-tailed).

The next step involved estimating the measurement model for behavior problems in Wave 1. The measurement model fit the data well: $\chi^{2}=86.43$, $\mathrm{df}=8$, Comparative Fit Index $=.96$, Tucker-Lewis Index $=.94$, Root Mean Square Error of Approximation $=.04$. The standardized factor loadings for the six items ranged from .42 to .78. Mplus generated and saved factor scores for all cases. This step simplified the number of parameters that had to be estimated in the structural analyses - a useful step, given the small number of adopted children in our sample.

Table 2 shows the results of an analysis in which the behavior problem variable was regressed on parental divorce and the control variables. Parameters were estimated simultaneously for biological and adopted children and were allowed to vary freely between the two groups. For biological children, the $b$ coefficient for divorce was .43. Because divorce was dichotomous and the dependent variable (behavior problems) was standardized, this coefficient can be interpreted as an effect size. In other words, biological children with divorced parents scored more than 40 percent of a standard deviation higher on the latent variable (on average) than did children with two continuously married parents. Most observers would consider an effect size of this magnitude to be moderate (Cohen 1988). The corresponding coefficient was large for children with adopted parents. The value of .81 indicates that adopted children with divorced parents scored more than three-fourths of a standard deviation higher than did adopted children with continuously married parents. (Note that this was a saturated model with no degrees of freedom, so the $\chi^{2}$ value was zero.) 
Because the effect size for divorce appeared to be larger for adopted children than for biological children, a second analysis constrained the divorce coefficicents to be equal across groups. The difference in chi-square values between the unconstrained and constrained models was not significant $\left(\Delta \chi^{2}=1.33, d f=1, p>.1\right)$. This result indicates that the estimated effect of divorce on children's behavior problems did not differ between the two groups of children. Of course, given the small size of the adopted sample, the power of this test to detect a significant difference between groups is weak. Nevertheless, the main finding - a statistically significant link between divorce and behavior problems in both groups despite the small number of adopted children - supports the standard family environment model.

\section{Marital Conflict and Children's Behavior Problems}

With respect to the longitudinal analysis, as in the cross-sectional analysis, biological and adopted children did not differ in age or gender. Adopted children, however, were more likely to have a mother respondent as well as a larger number of siblings. These differences reflect differential attrition and the removal of some families from the sample through divorce. As noted earlier, adopted children were more advantaged with respect to parent education and income than were biological children. Although marital conflict scores were lower for adopted children than for biological children, this difference did not attain statistical significance.

The next step required estimating a measurement model for parents' marital conflict in the two waves. The model involved two latent variables: one based on the main respondent's and spouse's reports of conflict in Wave 1, and the second on the main respondent's and spouse's reports of conflict in Wave 2. The factor loadings were constrained to be the same in both waves. This model fit the data well: $\chi^{2}=0.36, \mathrm{df}=1, \mathrm{CFI}=1.00, \mathrm{TLI}$ $=1.00$, RMSEA $=.00$. Factors scores based on the measurement model were saved for subsequent analyses.

Figure 2 shows the structural model for the two-wave analysis of marital conflict. This model included factor scores for children's behavior problems in both waves, along with the factor scores for marital conflict. The $t_{2}$ scores, with the $t_{1}$ scores controlled, are conceptually similar to change scores. In other words, the model estimates how changes in marital conflict between $t_{1}$ and $t_{2}$ were related to changes in behavior problems between $t_{1}$ and $t_{2}$. (The same principle applies to changes in behavior problems between $t_{1}$ and $t_{2}$ and changes in marital conflict between $t_{1}$ and $t_{2}$.) Although not shown in the figure, the model also includes the same control variables used in Table 2, along with family income.

The first test of this model pooled biological and adopted children and used a binary variable to reflect adoption status. The results of this analysis 
Figure 2. Reciprocal Paths Between Parents' Marital Conflict and Children's Behavior Problems

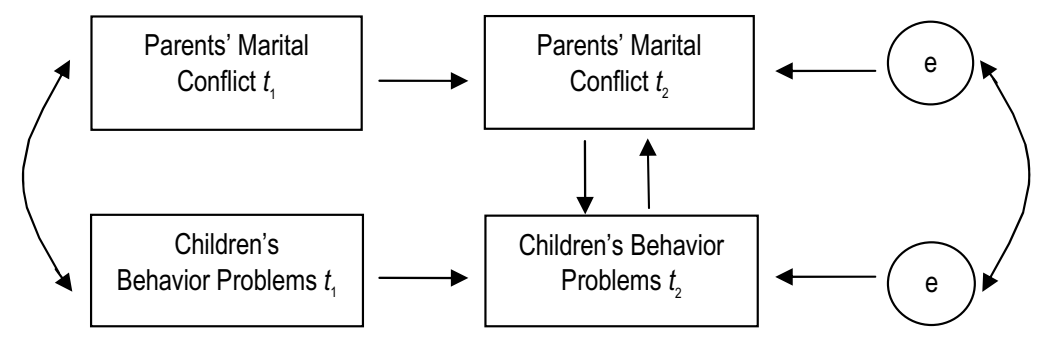

appear in Table 3. The stability coefficients between waves were moderate for both variables: .50 for marital conflict and .52 for children's behavior problems. The path from $t_{2}$ marital conflict to $t_{2}$ behavior problems was .21 $(p<.001)$, whereas the corresponding path from $t_{2}$ behavior problems to $t_{2}$ marital conflict was not significant. These results do not support the child effects model. Instead, they suggest that an increase in marital conflict was accompanied by an increase in children's behavior problems. (Because linear associations are symmetrical, the reverse also is true: A decrease in marital conflict was accompanied by a decline in children's behavior problems.) Changes in children's behavior problems, in contrast, did not predict changes in marital conflict. These results, however, cannot distinguish between the standard family environment model and the passive genetic model.

Separate analyses also were conducted for biological and adopted children. Because only 50 adopted children were in the analysis, the control variables were excluded. Although this exclusion did not affect the results, it kept the ratio of cases to parameters among adopted children in line with the minimum recommended by Kline (2005). When all parameters were allowed to vary freely across groups, the estimated effect of $t_{2}$ marital conflict on $t_{2}$ behavior problems was significant among biological children $(b=.23, \mathrm{SE}=.02, p<.001)$ and adopted children $(b=.28, \mathrm{SE}=.11$, $p<.05)$. The estimated effect of $t_{2}$ children's behavior problems on $t_{2}$ marital conflict was not significant for biological children (-.08) or adopted children (-.12). A test of the significance between coefficients yielded null results $\left(\Delta \chi^{2}=.983, \mathrm{df}=1, p=.683\right)$. Despite the small number of cases in the adopted sample, the key point is that the estimated effect of marital conflict on behavior problems was significant and comparable in magnitude in both groups. ${ }^{5}$

\section{Discussion}

We outlined three theoretical perspectives that account for the frequently replicated links between parents' marital distress and children's behavior 
Table 3: Associations Between Marital Conflict and Children's Behavior Problems

\begin{tabular}{|c|c|c|c|c|c|c|}
\hline \multirow[b]{3}{*}{ Predictors } & \multicolumn{6}{|c|}{ Dependent Variables } \\
\hline & \multicolumn{3}{|c|}{ Marital conflict $t_{2}$} & \multicolumn{3}{|c|}{ Behavior problems $t_{2}$} \\
\hline & $b$ & (SE) & beta & $b$ & (SE) & beta \\
\hline Marital Conflict $t_{1}$ & $.499^{\star * *}$ & $(.029)$ & .499 & - & - & - \\
\hline Marital Conflict $t_{2}$ & - & - & - & $.206^{\star * *}$ & $(.046)$ & .206 \\
\hline Behavior Problems $t_{1}$ & - & - & - & $.516^{\star \star \star}$ & $(.023)$ & .516 \\
\hline Behavior Problems $t_{2}$ & -.086 & $(.068)$ & -.086 & - & - & - \\
\hline Adopted & -.232 & $(.217)$ & -.042 & $.581^{* *}$ & $(.168)$ & .106 \\
\hline Parent Education & $-.027^{\star *}$ & $(.019)$ & -.076 & -.007 & $(.008)$ & -.020 \\
\hline Income (log) & .046 & $(.039)$ & .045 & -.048 & $(.031)$ & -.048 \\
\hline Parent Black & $.158^{*}$ & $(.075)$ & .056 & .006 & $(.059)$ & .002 \\
\hline Parent Hispanic & $.297^{\star *}$ & $(.102)$ & .081 & -.058 & $(.081)$ & -.016 \\
\hline Number of Siblings & $.052^{*}$ & $(.025)$ & .056 & -.032 & $(.019)$ & -.035 \\
\hline Child Age & $.157^{*}$ & $(.076)$ & .347 & $.050^{\star * *}$ & $(.008)$ & .250 \\
\hline Daughter & .057 & $(.055)$ & .028 & $-.127^{\star *}$ & $(.043)$ & -.063 \\
\hline Mother Respondent & .018 & $(.062)$ & .008 & -.009 & $(.048)$ & -.004 \\
\hline $\mathrm{R}^{2}$ & .343 & & & .387 & & \\
\hline
\end{tabular}

Note: $\mathrm{N}=1,464$.

${ }^{*} \mathrm{p}<.05 \quad{ }^{* *} \mathrm{p}<.01 \quad{ }^{* *} \mathrm{p}<.001$. (two-tailed).

problems. The standard family environment model assumes that marital conflict and divorce increase the risk of problematic outcomes for children. Two more recent perspectives challenge this model. The passive genetic model assumes that parents with problematic traits (such as neuroticism or a tendency to engage in antisocial behavior) are more likely than other parents to experience marital discord or see their marriages end in divorce. If these traits are transmitted genetically from parents to children, then the children of these marriages also will have an elevated risk of developing behavior problems. According to this perspective, the link between parents' marital distress and child problems is spurious, with the central causal mechanism being the genetic transmission of personality traits and behavioral predispositions from parents to children. The child effects model, in contrast, assumes that children who exhibit an elevated number of problems put stress on their parents' marriages, resulting in greater discord. Because most prior studies have relied on cross-sectional samples of biological parents and children, it has not been possible to distinguish between these three explanations.

The current study, based on two waves of data from biological and adopted children, provides consistent support for the standard family environment model. In the first analysis, based on the first wave of data from the NSFH, divorced parents reported more behavior problems among their children than did continuously married parents - a result consistent with a large number of prior studies (Amato 2000). More importantly, 


\section{4 - Social Forces Volume 86, Number 3 • March 2008}

divorce was associated significantly with behavior problems among adopted as well as biological children. These results support the standard family environment model.

The longitudinal analysis examined the links between parents' marital conflict and children's behavior problems using models with reciprocal paths. Consistent with the standard family environment model, the estimated path from marital discord to behavior problems was statistically significant (see Table 3). Moreover, the estimated path from marital discord to behavior problems was significant among adopted as well as biological children. Contrary to the child effects model, the estimated causal path from behavior problems to marital discord was not significant, either in the pooled sample or in the separate samples of biological and adopted children. These results provide consistent support for the standard family environment model.

Without experimental data, one cannot reach definitive conclusions about causality. Nevertheless, the current research finds consistent evidence that marital conflict and divorce increase the risk of children's problems. Being able to rule out alternative explanations, including child effects and passive genetic effects, is a strength of this study. Researchers who have relied on the standard family environment model in their work are likely to be pleased with these results. Nevertheless, it would be a mistake to conclude that the standard family environment model is "correct" and that the other two models are "wrong." Indeed, all three models are probably necessary to understand children's development, depending on the type of outcome examined.

The present study focused on six behavior problems: repeating a grade, getting in trouble at school, being suspended or expelled from school, having trouble with the police, seeing a doctor or therapist about an emotional or behavioral problem, and being particularly difficult to raise. Although the first item partly taps academic ability, and the item on seeing a doctor or therapist partly taps emotional problems, most of the items focus on externalizing behavior. The current results, therefore, are consistent with those of O'Connor et al. (2000), who found that the associations between parental divorce and children's behavior problems were comparable for adopted and biological children. The O'Connor study also found, however, that the associations between parental divorce and children's school and social adjustment were stronger among biological children than adopted children. Because we did not have measures of school and social adjustment for the children in our sample, it is not possible to compare our findings directly with those of $\mathrm{O}^{\prime} \mathrm{Connor}$. It is possible that some child outcomes, such as the behavior problems we studied, are due largely to the family environment, whereas other outcomes, such as social competence, are affected more strongly by genetic factors. Additional studies that compare samples of adopted and biological children across a range of outcomes are 
necessary to determine which child outcomes are primarily responsive to parental behavior and which are primarily affected by parents' genes.

Other studies have provided strong evidence of child effects, with the research literature on parental monitoring being a good example (Crouter and Head 2002; Stattin and Kerr 2000). Although children's misbehavior does not appear to be a major cause of parents' marital distress, children's misbehavior may affect other aspects of parents' behavior, such as their use of harsh discipline or their expressions of warmth. Future studies that model reciprocal effects between parents and children are necessary to distinguish aspects of parent-child interaction that are primarily shaped by children rather than parents. Of course, a good deal of parent-child interaction probably reflects child as well as parent effects. This view is consistent with the position that family dynamics are best represented as a reciprocal process unfolding over time, with each family member adapting to other family members (Maccoby 2003).

A major limitation of this study was its reliance on a relatively small number of adopted children: 120 in the cross-sectional analysis and 50 in the longitudinal analysis. Even in a large sample such as the NSFH, the number of adopted children is modest. The small sample of adopted children (and the corresponding weak statistical power to reject the null hypothesis) would have been a serious problem if we had failed to find significant associations among adopted children. Statistical power was not a problem, however, because the estimated effects of divorce and marital conflict among adopted children were significant. Nevertheless, future data collection efforts that oversample adopted children would make it possible for researchers to parse genetic from environmental effects more effectively.

Another limitation of this study was its focus on a relatively simple version of the genetic model. In particular, we were unable to examine gene-by-environment interactions. Many behavior geneticists believe that environmental factors can activate or deactivate particular genes (Plomin 1994; Reiss et al. 2000). In other words, a genetic predisposition for children to engage in a certain behavior may be expressed in some families but not in others, depending on parental behavior and other environmental circumstances. Relatively few genetically informed studies have attempted to model gene by environment interactions, partly because the typical twin design is not sensitive to interactions (Reiss et al. 2000) Nevertheless, several studies have shown that adopted children with troubled biological parents (for example, parents with substance abuse problems or antisocial traits) are especially likely to exhibit behavior problems if they are reared in unfavorable family environments (Cadoret, Yates, Troughton, Woodworth and Steward 1995).

In conclusion, the present study is one of the first to assess three theoretical models that link parents' marital distress with children's behavior 
problems. The analysis provides little support for the passive genetic or the child effects models. Genetic influences on children's behavior are probably common, however, as are children's effects on parents. Nevertheless, in the midst of new perspectives that challenge traditional thinking about the family, we should not forget that the basic premise of socialization theory that parents influence their children's development, for better or for worse - continues to be a reasonable and useful guide for much research.

\section{Notes}

1. A logistic regression analysis revealed that attrition was elevated among blacks, Latinos, fathers, poorly-educated respondents and lowincome respondents. Attrition was not related to the adoption status of the child, the child's age, the child's gender, the number of children in the family, the child's behavior problems or the parents' level of marital conflict. Because attrition was not related to the independent or dependent variables, it is unlikely to have affected estimates. For this reason, we did not adjust for attrition in our longitudinal analysis.

2. The amount of missing data for most variables was modest (less than 5 percent of cases). The exception involved spouses' reports of conflict in Waves 1 and 2. For these variables, missing data represented 19 percent and 33 percent of cases, respectively. We used a weighted least squares estimator and the common assumption that missingness was random, conditional on the observed variables, so that cases with full and partial information were included in the analysis.

3. Several alternatives were available for scaling the behavior problem items. In supplementary analyses, we used negative binomial regression, Poisson regression and zero-inflated Posisson regression models (DeMaris 2004). All of these methods yielded results that were substantively the same as the results from the IRT procedure reported in the text.

4. A cross-lagged model is an alternative to the reciprocal (or contemporaneous) effects model in our analysis. A $t_{2}$ score with its $t_{1}$ equivalent controlled is conceptually similar to a change score. Consequently, a cross-lagged model estimates the effect of a variable measured at $t_{1}$ (such as marital conflict) on change in a second variable (such as behavior problems) between $t_{1}$ and $t_{2}$. The reciprocal paths model, in contrast, estimates the effects of change on change. When modeling family processes in which individuals or dyads mutually influence one another over time, the contemporaneous model appears to be more appropriate theoretically. Nevertheless, because some readers may be interested in the cross-lagged results, we present these in a subsequent endnote.

5. Cross-lagged models yielded substantive conclusions that were identical to those reported in Table 3. That is, the estimated effect of $t_{1}$ 
marital conflict on $t$, behavior problems was significant $(b=.17$, SE $=$ $.08, p<.05$ ) whereas the estimated effect of $t$, behavior problems on $t_{2}$ marital conflict was not $(p>.10)$. When we examined biological and adopted children separately, the results were similar to those reported in the text. For biological children, the path from $t$ marital conflict to $t$ behavior problems was significant $(b=.10, \mathrm{SE}=.02, p<.001)$. The corresponding path was in the same direction and marginally significant for adopted children $(b=.35, \mathrm{SE}=.19, p=.075)$. The estimated effect of $t_{1}$ behavior problems on $t_{2}$ marital conflict was not significant for biological or adopted children (both $p>.10$ ).

\section{References}

Amato, Paul R. 2000. "Consequences of Divorce for Adults and Children." Journal of Marriage and the Family 62(4):1269-87.

2003. "Reconciling Divergent Perspectives: Judith Wallerstein, Quantitative Family Research, and Children of Divorce." Family Relations 52(4):332-39.

Amato, Paul R., and Alan Booth. 1995. "Changes in Gender Role Attitudes and Marital Quality." American Sociological Review 60(1):58-66.

1997. A Generation at Risk: Growing up in an Era of Family Upheaval. Harvard University Press.

Amato, Paul R., and Alan Booth. 2001. "The Legacy of Marital Discord: Consequences for Children's Marital Quality." Journal of Personality and Social Psychology 81(4):627-38.

Amato, Paul R., and Denise Previti. 2003. "People's Reasons for Divorcing: Gender, Social Class, the Life Course, and Adjustment." Journal of Family Issues 24(5):602-26.

Ambert, Anne-Marie. 2001. The Effect of Children on Parents. Haworth Press.

Bell, Richard Q. 1968. "A Reinterpretation of the Direction of Effects in Studies of Socialization." Psychological Review 75(2):81-95.

Bollen, Kenneth A. 1989. Structural Equations with Latent Variables. Wiley.

Booth, Alan, and Paul R. Amato. 2001. "Parental Predivorce Relations and Offspring Postdivorce Well-being." Journal of Marriage and the Family 63(1):197-212.

Brody, Gene, E. Neubaum and Rex Forehand. 1988. "Serial Marriage: A Heuristic Analysis of an Emerging Family Form." Psychological Bulletin 103(2):211-22.

Brodzinsky, David, Jennifer C. Hitt and Daniel Smith. 1993. "Impact of Parental Separation and Divorce on Adopted and Nonadopted Children." American Journal of Orthopsychiatry 63(3):451-61. 


\section{8 • Social Forces Volume 86, Number 3 • March 2008}

Cadoret, Remi J., William R. Yates, Ed Troughton, George Woodworth and Mark A. Steward. 1995. "Genetic-Environmental Interaction in the Genesis of Aggressivity and Conduct Disorders." Archives of General Psychiatry 52(11):916-25.

Capaldi, Deborah M., and Gerald R. Patterson. 1991. "Relation of Parental Transitions to Boys' Adjustment Problems: 1. A Linear Hypothesis; 2. Mothers at Risk for Transitions and Unskilled Parenting." Developmental Psychology 27(3):489-504.

Ceballo, Rosario, Jennifer E. Lansford, Antonia Abbey and Abigail J. Stewart. 2004. "Gaining a Child: Comparing the Experiences of Biological Parents, Adoptive Parents, and Stepparents." Family Relations 53(1):38-48.

Cherlin, Andrew. 1999. "Going to Extremes: Family Structure, Children's WellBeing, and Social Science." Demography 36(4):421-29.

Cherlin, Andrew J., P. Lindsay Chase-Lansdale and Christine McRae. 1998. "Effects of Divorce on Mental Health Throughout the Life Course." American Sociological Review 63(2):239-49.

Cohen, Jacob. 1988. Statistical Power Analysis for the Behavioral Sciences $12^{\text {nd }}$ edition). Erlbaum.

Crouter, Ann C., and Melissa R. Head. 2002. "Parental Monitoring and Knowledge of Children." Pp. 461-83. Handbook on Parenting (2nd edition). Marc H. Bornstein, editor. Erlbaum.

DeMaris, Alfred. 2004. Regression with Social Data: Modeling Continuous and Limited Response Variables. Wiley-Interscience.

Crockenberg, Susan, and Esther Leerkes. 2003. "Infant Negative Emotionality, Caregiving, and Family Relationships." Pp. 57-78. Children's Influence on Family Dynamics: The Neglected Side of Family Relationships. Ann C. Crouter and Alan Booth, editors. Erlbaum.

Crouter, Ann C., and Alan Booth. 2003. Children's Influence on Family Dynamics: The Neglected Side of Family Relationships. Erlbaum.

Cummings, E. Mark. 1987. "Coping with Background Anger in Early Childhood." Child Development 58(4):976-84.

Davies, Patrick T., and E. Mark Cummings. 1994. "Marital Conflict and Child Adjustment: An Emotional Security Hypothesis." Psychological Bulletin 116(3):387-411.

DeMaris, Alfred. 2004. Regression with Social Data: Modeling Continuous and Limited Response Variables. Wiley.

Emery, Robert E. 1999. Marriage, Divorce, and Children's Adjustment. Sage. 
Divorce, Conflict and Child Behavior Problems • 1159

Fomby, Paula, and Andrew J. Cherlin. 2007. "Family Instability and Child WellBeing." American Sociological Review 72(2):181-204.

Gerard, Jean M., Ambika Krishnakumar and Cheryl Buehler. 2006. "Marital Conflict, Parent-Child Relations, and Youth Maladjustment: A Longitudinal Investigation of Spillover Effects." Journal of Family Issues 27(7):951-75.

Gruber, Jonathan. 2004. "Is Making Divorce Easier Bad for Children? The Long-Run Implications of Unilateral Divorce." Journal of Labor Economics 22(4):799-834.

Grych, John H., and Frank D. Fincham. 1990. "Marital Conflict and Children's Adjustment: A Cognitive-Contextual Framework." Psychological Bulletin 108(2):267-90.

Hambleton, Ronald K., H. Swaminathan and H. Jane Rogers. 1991. Fundamenta/s of Item Response Theory. Sage.

Hamilton, Laura, Simon Cheng and Brian Powell. 2007. "Adoptive Parents, Adaptive Parents: Evaluating the Importance of Biological Ties for Parental Investment." American Sociological Review 72(1):95-116.

Harris, Judith R. 1998. The Nurture Assumption : Why Children Turn Out the Way They Do. Free Press.

Haveman, Robert H. 1994. Succeeding Generations: On the Effects of Investment in Children. Russell Sage.

Hetherington, E. Mavis, and W. Glenn Clingempeel. 1992. "Coping with Marital Transitions." Monographs of the Society for Research in Child Development 57, nos. 2-3. University of Chicago Press.

Hetherington, E. Mavis, and K.M. Jodl, 1994. "Stepfamilies as Settings for Child Development. Pp. 55-79. Stepfamilies: Who Benefits? Who Does Not? Alan Booth and Judy Dunn, editors. Erlbaum.

Hetherington, E. Mavis and John Kelly. 2002. For Better or For Worse: Divorce Reconsidered. W.W. Norton.

Jockin, Victor, Matt McGue and David T. Lykken. 1996. "Personality and Divorce: A Genetic Analysis." Journal of Personality and Social Psychology 71(2):288-99.

Jöreskog, Kark G., and Dag Söorbom. 1988. LISREL 7: A Guide to the Program and Applications. Chicago, II: SPSSI Inc.

Kline, Rex B. 2005. Principles and Practice of Structural Equation Modeling $\left(2^{\text {nd }}\right.$ edition). 2005. Guilford.

Krishnakumar, Ambika, and Cheryl Buehler. 2000. "Interparental Conflict and Parenting Behaviors: A Meta-Analytic Review." Family Relations 49(1):25-44. 


\section{0 • Social Forces Volume 86, Number 3 • March 2008}

Lansford, Jennifer E., Rosario Ceballo, Antonia Abbey and Abigail J. Stewart. 2001. "Does Family Structure Matter? A Comparison of Adoptive, Two-Parent Biological, Single-Mother, Stepfather, and Stepmother Households." Journal of Marriage and Family 63(3):840-51.

Maccoby, Eleanor E. 2003. "The Gender of Child and Parent as Factors in Family Dynamics." Pp. 191-206. Children's Influence on Family Dynamics: The Neglected Side of Family Relationships. Ann C. Crouter and Alan Booth, editors. Erlbaum.

McLanahan, Sara, and Gary Sandefur. 1994. Growing Up with a Single Parent: What Hurts, What Helps. Harvard University Press.

McCartney, Kathleen. 2003. "On the Meaning of Models: Signals Amidst the Noise." Pp. 27-36. Children's Influence on Family Dynamics: The Neglected Side of Family Relationships. Ann C. Crouter and Alan Booth, editors. Erlbaum.

McGue, Matt, and David T. Lykken. 1992. "Genetic Influence on Risk of Divorce." Psychological Science 3(6):368-73.

Muthén, Linda K., and Bengt O. Muthén. 2005. Mplus User's Guide (3rd edition). Muthén \& Muthén.

O'Connor, Thomas G., Avshalom Caspi, John C. DeFries and Robert Plomin. 2000. "Are Associations Between Parental Divorce and Children's Adjustment Genetically Mediated? An Adoption Study." Developmental Psychology 36(4):420-37.

Osgood, D. Wayne, Barbara J. McMorris and M. T. Potenza. 2002. "Analyzing Multiple-Item Measures of Crime and Deviance I: Item Response Theory Scaling." Journal of Quantitative Criminology 18(3):267-96.

Plomin, Robert. 1994. Genetics and Experience: The Interplay between Nature and Nurture. Sage.

Plomin, Robert, G.E. McClearn, Nancy L. Pedersen, John R. Nesselroade and C.S. Bergeman. 1989. "Genetic Influence on Adults' Ratings of their Current Family Environment." Journal of Marriage and the Family 51(3):791-803.

Pong, Suet-Ling, Jaap Dronkers and Gillian Hampden-Thompson. 2003. "Family Policies and Children's School Achievement in Single- Versus Two-Parent Families." Journal of Marriage and Family 65(3):681-99.

Reiss, David. 2001. "Child Effects on Family Systems: Behavioral Genetic Strategies." Pp. 3-25. Children's Influence on Family Dynamics: The Neglected Side of Family Relationships. Ann C. Crouter and Alan Booth, editors. Erlbaum. 
Reiss, David, Jenae M. Neiderhiser, E. Mavis Hetherington and Robert Plomin. 2000. The Relationship Code: Deciphering Genetic and Social Influences on Adolescent Development. Harvard University Press.

Rowe, David. 1994. The Limits of Family Influence: Genes, Experience, and Behavior. Guildford Press.

Stattin, Häkan, and Margaret Kerr. 2000. "Parental Monitoring: A Reinterpretation." Child Development 71(4):1072-85.

Sweet, Jim A., and Larry L. Bumpass. 1996. The National Survey of Families and Households - Waves 1 and 2: Data description and documentation. University of Wisconsin-Madison: Center for Demography and Ecology.

Sweet, Jim A., Larry L. Bumpass and Vaughn Call. 1988. The Design and Content of the National Survey of Families and Households. University of WisconsinMadison: Center for Demography and Ecology.

Thornberry, Terence P., Carolyn A. Smith, Craig Rivera, David Hjizinga and Magda Stouthamer-Loeber 1999. "Family Disruption and Delinquency." Juvenile Justice Bulletin. September 1999. Washington, D.C.: U.S. Department of Justice.

Towers, Hilary, Erica L. Spotts and Jenae M. Neiderhiser. 2001. "Genetic and Environmental Influences on Parenting and Marital Relationships: Current Findings and Future Directions." Marriage and Family Review 33(1):11-29.

Winship, Christopher, and Larry Radbill. 1994. "Sampling Weights and Regression Analysis." Sociological Research \& Methods 23(2):230-57. 